\title{
A Whole Institution Approach to Climate Change Education
}

\author{
Preparing School Systems to Be Climate Proactive
}

Kristen Hargis, Marcia McKenzie, and Isabelle LeVert-Chiasson

\begin{abstract}
Few studies have investigated a "whole institution" approach in relation to climate change education (CCE), despite its importance in achieving a culture of sustainability and climate action. Responding to this imperative, unesco launched a "Getting Climate-Ready" pilot project across 25 countries through their Associated Schools Project Network (ASPnet). This pilot project integrated climate action into the domains of teaching and learning, facilities and operations, community partnerships, and school governance. In Canada, 10 primary and secondary schools participated under the direction of the Canadian Commission for Unesco. The Sustainability and Education Policy Network (SEPN) evaluated CCE engagement in these 10 pilot schools as well as in 17 non-pilot ASPnet schools across Canada. This chapter documents the promising climate action practices identified through this evaluation. Insights for increased climate action at school, school division, and ministry of education levels are also included from a recently developed CCE primer. The chapter provides entry points for transforming education systems through a cross-site comparative analysis of a whole institution approach to CCE across Canada.
\end{abstract}

\section{Keywords}

climate change education - whole institution - comparative case-study - whole school approach

At the time of writing, the world is facing a pandemic that has infected millions of people and claimed more than a million lives (WHO, 2O2O). Connected to this global health crisis is a climate catastrophe the likes of which

(C) UNESCO IBE, 2021 | DOI: 10.1163/9789004471818_004

This is an open access chapter distributed under the terms of the CC BY 4.o License. 
is comparable to that of the dinosaur extinction (Glikson, 2016). As the climate warms, the potential for future virus outbreaks also increases (Costello et al., 2009; Watts et al., 2018; wHO, n.d.), with some arguing we are entering a "pandemic era" due in part to human-caused climatic alterations (Jandu, 2020; Morens \& Fauci, 202O). Addressing climate change is essential not only to reduce the likelihood of future health disasters, but also for the survival of humanity, and time is of the essence (IPCC, 2018).

In October 2018, the Intergovernmental Panel on Climate Change (IPCC) released a landmark Special Report on Climate Change, warning that 12 years remained to prevent climate catastrophe. Their unprecedented message beseeched nations to increase climate change education (CCE) to "accelerate the wide scale behaviour changes consistent with adapting to and limiting global warming" (IPCC, 2018, p. 22). The IPCC's imperative joins international calls for CCE, dating back to 1992, when the United Nations Framework Convention on Climate Change (UNFCCC) ratified Article 6, encouraging governments to educate all stakeholders on climate change. More recently, the importance of CCE was acknowledged in Article 12 of the Paris Agreement (UNFCCC, 2015) and in the UNFCCC launching of the Action for Climate Empowerment guidelines in collaboration with UNESCO (UNESCO \& UNFCCC, 2016). Calls for CCE were further strengthened when the United Nations developed the 2030 Agenda for Sustainable Development in 2015, which includes 17 Sustainable Development Goals (SDGs) for achieving sustainability and tackling climate change. Goal 13, in particular, encourages nations to "improve education, awareness-raising and human and institutional capacity on climate change mitigation, adaptation, impact reduction and early warning" (SDSN, 2015). Goal 4 (inclusive and quality education for all) also encompasses CCE through Indicator 4.7, which specifies that all learners should acquire the knowledge and skills needed to promote sustainable development by 2030 (SDSN, 2015).

Without doubt, educational potential exists to engender the large-scale transformation required to address sustainable development and climate change, a fact long recognized by UNESCO. Indeed, in 1953 UNESCO established what would later become known as the Associated Schools Project Network (ASPnet) to link educational institutions around a common goal: promoting quality education in pursuit of peace and sustainable development (UNESCO, 2018). Currently more than 11,0oo schools in 182 countries have joined ASPnet (UNESCO, 2018). Schools usually join ASPnet to have the chance to join a global initiative and to receive the legitimation offered through association with UNESCO (Shultz \& Guimares-Iosif, 2012; Shultz et al., 2009). ASPnet is recognized by UNESCO as an effective mechanism for contributing to SDG 4 to achieve Target 4.7 on Global Citizenship Education (GCED) and Education for Sustainable Development (ESD), as well as Target 13.3 on climate action. 
In 2016, UNESCO launched the Getting Climate-Ready pilot project within their ASPnet schools across 25 countries to help them engage in climate actions to limit climate change and adapt to its effects. Worldwide, the project reached approximately 200,000 students and 12,000 teachers (UNESCO, 2016). Within Canada, 10 primary and secondary schools participated under the direction of the Canadian Commission for UnEsco. The aim of the project was for schools to implement a "whole institution" approach to CCE. A whole institution approach seeks to develop a school culture of sustainability, in which all aspects of school life support and advance climate action (Henderson \& Tilbury, 2004; UNESCO, 2016).

As part of the pilot project, UNEsco widely distributed the Getting Climate-Ready guide as well as a list of climate change teaching and learning resources (UNESCO, 2016). The Getting Climate-Ready guide provides a stepby-step framework to help schools become more climate friendly (UNESCO, 2016). Its development was informed by scholarly literature, national and international guidelines, and program websites, as well as a survey of climate action projects already happening in 55 ASPnet schools in 12 countries (UNESCO, 2016). Pilot ASPnet schools were provided with in-person training. Non-pilot ASPnet schools were sent a link to the Getting Climate-Ready guide through the ASPnet newsletter but did not receive in-person training. In 2016, to aid project completion UNESCO also launched the ASPnet online tool (отA), a new participatory hub on the whole institution approach to ESD.

The Sustainability and Education Policy Network (SEPN) evaluated the project's success in pilot and non-pilot schools across Canada. SEPN collected information from 10 Canadian ASPnet schools that participated in the Getting Climate-Ready pilot project, as well as data from an additional 17 Canadian ASPnet schools not participating in the pilot. The evaluation goal was to identify good practices of climate action in Canadian UNESCO ASPnet schools, using a whole institution approach as a lens. The evaluation resulted in datadriven (Chopin et al., 2018) and story-based (Hargis et al., 2018) reports, which provide the basis for the contributions in this chapter.

SEPN used the Getting Climate-Ready guide to identify variables related to a whole institution approach, as well as the scholarly literature on "good" CCE to evaluate the success of the project in the pilot and non-pilot ASPnet schools. The scholarly literature upon which SEPN drew is reviewed in the next section.

While the field of CCE is still emerging, research suggests that "good" CCE should involve all areas of institutional activity (Bieler et al., 2018; Henderson \& 
Tilbury, 2004; UNESCO, 2016). A "whole institution" or "whole school" approach to climate change involves engagement within and across the areas of school governance, teaching and learning, facilities and operations, and community partnerships (Bieler et al., 2018; UNESCO, 2016; see Figure 3.1). ${ }^{1}$

\section{Whole Institution Approach}

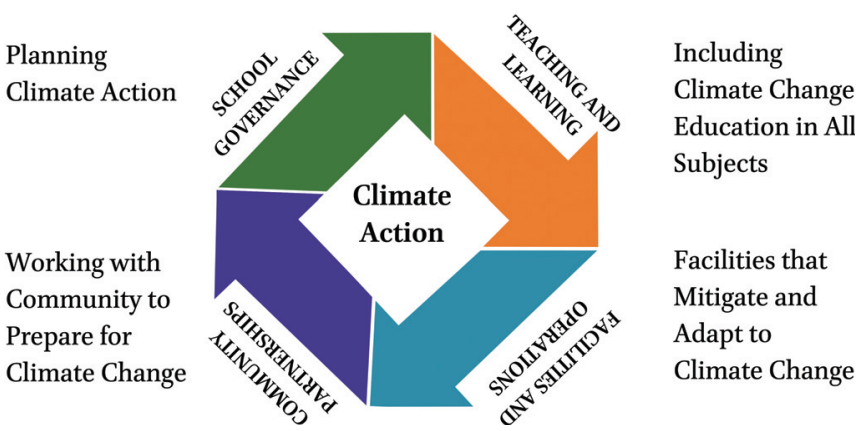

FIGURE 3.1 Overview of a whole institution approach to CCE (Chopin et al., 2018)

A whole institution approach pivots focus from individuals to school communities working toward climate actions together. Indeed, "The key to successfully implementing the whole school approach is to involve students, teachers, principals, school staff at all levels, and the wider school community such as families and community members - in reflecting and acting on climate change" (CCUNESCO, 2020, p. 26). The active involvement of all educational stakeholders, both inside and outside the school, is a crucial component of this approach (UNESCO, 2016). Some key climate actions recommended in a whole institution approach and by the Getting Climate-Ready guide are summarized in Figure 3.2 (UNESCO, 2016; also see Hargis \& McKenzie, 2020). While listed separately in Figure 3.2, in practice, the domains often interact with one another, with climate action initiatives often linked to more than one domain.

While all domains of institutional activity are important when using a whole institution approach, schools are often most explicitly focused on the area of teaching and learning. Most CCE to date within this whole-school area has focused on learning facts about climate change, assuming that increased scientific literacy will lead to changed beliefs and behaviors (Brownlee et al., 2013; González-Gaudiano \& Meira-Cartea, 2010; UnESCO, 2019a; Wibeck, 2014). Evidence suggests, however, that higher levels of scientific knowledge do not automatically change minds or mobilize feet, and that even belief in climate change only moderately affects actions (Callison, 2014; CRED, 2009; Hornsey et al., 2016; Kahan et al., 2012; Lee et al., 2015). 


\section{What Schools Can Do Now in Each of the Four Whole Institution Areas}

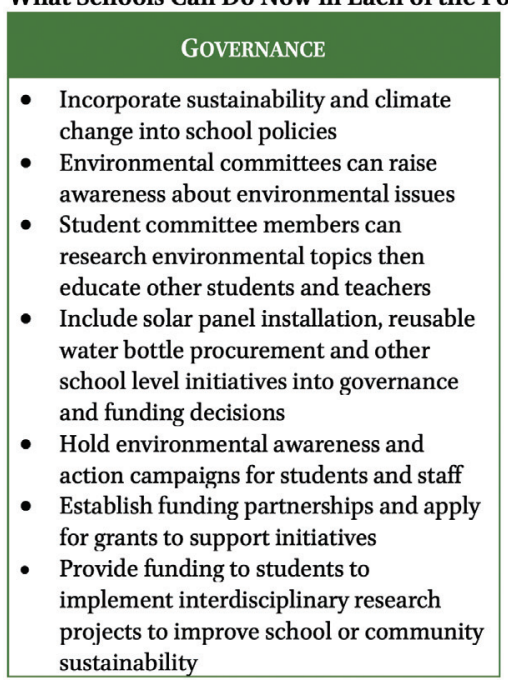

COMMUNITY PARTNERSHIPS

- Develop a website to track school's whole institution approach and support monthly climate change challenges

- Collaborate with other schools, neighborhood associations, local businesses, local organizations, and networks on climate action

- Students can learn about reducing emissions then teach others, including their families, about eco-friendly lifestyles

- Students can collaborate with partners based on a real-life need of an environmental group

- Can establish and care for school gardens with community partners

- Students can work with partners to host climate-related community events

\section{TEACHING \& LEARNING}

- Integrate education for sustainable development across entire curriculum

- Hold school-wide challenges to reduce climate change

- Develop classroom- and school-level projects on climate change

- Extend learning outside the classroom through community partnerships

- Incorporate learning about Indigenous cultures, the environment, and climate change for students

- Have students research local actions for reducing the community's impact in relation to climate change

- Hold workshops and conferences on sustainability and climate change-related topics

- Foster connections to place by bringing classes outside

\section{FACILITIES \& OPERATIONS}

- Plant native flowers, trees, fruits, and vegetables

- Buy products that are local and made ethically

- Turn off lights and electronics when not in use

- Encourage staff and students to bring litter-less lunches and conserve water

- Establish student-led recycling and compost programs and teach proper waste sorting

- Install solar panels and water bottle fountains

- Cook with local products in the cafeteria

- Host Carbon Reduction Challenges to encourage staff and students to find more eco-friendly methods of transportation

FIGURE 3.2 Examples of climate action in each whole institution domain identified from the Getting Climate-Ready guide (UnEsCO, 2016) and SEPN's evaluation (Chopin et al., 2018; Hargis et al., 2018; Hargis \& McKenzie, 2020)

The research suggests that "good" CCE should focus on the cognitive, socioemotional, and behavioral ("action") dimensions of learning and should also be oriented toward the social justice concerns of climate change (GonzálezGaudiano \& Meira-Cartea, 2010; UNESCO, 2015, 2019b; also see Figure 3.3). The cognitive domain emphasizes acquiring accurate information that fosters critical thinking and media literacy skills (UnEsCO, 2015). The focus on criticality is essential because of media trends suggesting there are two "sides" to 


\section{Cross-disciplinary research suggests climate change education} should focus on the following learning dimensions:

\begin{tabular}{|c|c|c|c|}
\hline Cognitive & Socio-emotional & Action-oriented & Justice-focused \\
\hline $\begin{array}{l}\text { Teach the } \\
\text { scientific } \\
\text { consensus on } \\
\text { climate change } \\
\text { - Foster critical } \\
\text { thinking skills } \\
\text { and media } \\
\text { literacy }\end{array}$ & \begin{tabular}{|l} 
Incorporate socio- \\
emotional \\
considerations to \\
overcome feelings \\
of eco-anxiety, \\
denial, and \\
inaction
\end{tabular} & $\begin{array}{l}\text { - Use teaching } \\
\text { methods that are } \\
\text { participatory and } \\
\text { place-based } \\
\text { - Focus on } \\
\text { collective action }\end{array}$ & \begin{tabular}{|l} 
- \\
Link and \\
strategize with \\
other justice- \\
related issues \\
- \\
Address who \\
benefits and is \\
most affected by \\
our collective \\
inaction
\end{tabular} \\
\hline
\end{tabular}

FIGURE 3.3 Key elements of "good" CCE, which include cognitive, socio-emotional, behavioral ("action"), and justice-oriented components (from Hargis \& McKenzie, 2020). (The literature that informed the creation of this figure is: Amel et al., 2017; Brownlee et al., 2013; CRED, 2009; Hornsey et al., 2016; Kahan et al., 2012; Monroe et al., 2017; Plutzer et al., 2016; Tuck \& McKenzie, 2015; UNESCO, 201O, 202O; Wibeck, 2014)

climate science, which can contribute to student confusion at best and mistrust of science at worst (Doherty \& Clayton, 2011; González-Gaudiano \& Meira-Cartea, 2010). Educational approaches such as critical media literacy can teach students how to sort fact from fiction (UNESCO, n.d.). Additionally, misinformation in the classroom could further confuse students. Recent research analyzing Canadian science curricula and textbooks found they focused on human-caused warming as a debate, not on the scientific consensus, with one province (Manitoba) recommending reading materials from the climate denier organization Friends of Science within its supplementary curriculum materials (Wynes \& Nicholas, 2019). To prevent climate confusion, CCE must include accurate information and encourage critical thought (Plutzer et al., 2016).

As students' knowledge about climate change grows, they may develop eco-anxiety, illustrating the importance of including socio-emotional components within CCE (Doherty \& Clayton, 2011; Norgaard, 2011; Randall, 2009; see Figure 3.3). While small doses of concern can spur action, feeling anxious can result in passivity and hopelessness (Clayton et al., 2017). In light of growing reports of youth experiencing eco-anxiety (Elks, 2019; Johnson, 2007; Lawrynuik, 2019), educational approaches must bolster students' agency and empower them to feel that they, and society, can and are taking meaningful climate action (Threadgold, 2012; UNESCO, 2010).

Socio-emotional components of CCE also include cultural and political considerations (Callison, 2014). Indeed, evidence suggests that the greatest predictors of climate belief and action are cultural and political affiliation (Callison, 2014). A recent study found, for instance, that teachers' political views, as 
opposed to their content knowledge, more accurately predicted how CCE was taught (Plutzer et al., 2016). The importance of considering political and cultural associations is also illustrated in a range of interdisciplinary work emphasizing the role of language and framing in making climate change matter in relation to the priorities of different communities to overcome prior doubt and inaction (Kahan et al., 2012; Lee et al., 2015; Rowling, 2019).

Related to political considerations are those of climate justice, as those who suffer the worst consequences of climate change have often contributed the least to creating the problem (United Nations, 2019; Kanbur, 2015). Climate justice also intersects with other social and ecological justice issues, such as colonization, racism, sexism, classism, ableism, and xenophobia (Godfrey, 2012; Godfrey \& Torres, 2016). Failure to address underlying and systemic issues not only "maintains, and even strengthens the status quo ... [but it also] keeps us in an endless cycle of ineffective band-aids while domination, extraction, and oppression persist" (Godfrey \& Torres, 2016, p. xxv).

As students engage with climate justice and climate change, there is also growing urgency for educators to aid students in overcoming feelings of climate confusion, pessimism, and hopelessness through action (Li \& Monroe, 2017; Ojala, 2017; Stevenson \& Peterson, 2016; see Figure 3.3). Action-oriented responses are crucial, as students may disengage with climate change issues if they are perceived as unsolvable (Amel et al., 2017; Monroe et al., 2017; Rowling, 2019). For example, schools and school boards can establish policies preventing penalization of student participation in the Global Climate Strikes (see свС, 2019b). In addition, social learning and place-based pedagogies are critical in moving beyond climate and environmental awareness to empowerment and action (CRED, 2009). Inclusion of local problems and solutions demonstrates that climate change issues are local and actionable. Thus, how CCE is taught is just as important as the content (Orr, 2011). To move beyond cognitive learning to socio-emotional, action, and justice-oriented engagement on climate change, CCE must occur across all subject areas. If CCE occurs only in science classrooms, students may think that climate change has only scientific or technical solutions, rather than understanding that it also requires social and political analysis and action (Hornsey et al., 2016).

To summarize, a whole institution approach encourages CCE within and across all domains of school life (Bieler et al., 2018; UNESCO, 2016). In the area schools are most focused on, teaching and learning, the scholarly literature indicates that climate change should be taught across all subjects and should incorporate cognitive, socio-emotional, action, and justice-oriented, components. These considerations were key for SEPN's evaluation. The next section gives an overview of the methods SEPN used. 
Data were collected from 10 pilot project participants through a pre-interview survey, as well as semi-structured telephone interviews (for more details see Chopin et al., 2018). An additional 17 non-pilot schools responded to the survey to collect comparative data on current climate action practices happening at ASPnet schools without the support of the Getting Climate-Ready pilot project (i.e., non-pilot ASPnet schools, which did not receive in-person training in relation to the Getting Climate-Ready guide; they only received the guide via the ASPnet newsletter).

This chapter focuses on the climate action stories collected and analyzed qualitatively (for details on the quantitative analysis and results see Chopin et al., 2018). Qualitative data analysis involved inductive thematic analysis of stories and open-ended responses collected via the survey and interviews to identify good practices, as well as factors associated with successes and challenges as identified by the participants. Key emergent themes were developed in consideration to the Getting Climate-Ready guide and the scholarly literature, wherein "good" practices are those that incorporate climate action within and across whole institution domains and that integrate cognitive, socio-emotional, action, and justice-oriented components.

\section{4}

\section{Promising Practices and Next Steps}

The following discussion of promising practices and next steps highlights emergent themes across pilot and non-pilot schools and provides suggestions for future direction and action, incorporating insights from a recently developed CCE primer (a practical guide based in part on SEPN's CCUNESCO evaluation) and prior SEPN research. Where possible, we also give suggestions for application of the school-level findings to inform action at the levels of school divisions (known elsewhere as school districts) and ministries of education. Together, the results and discussion provide entry points for transforming education systems into institutions focused on climate action.

\subsection{Collaborative Networks}

Throughout our analysis of Canadian ASPnet schools, it was very apparent how much the schools learn from each other (through such avenues as climate change challenges, Carbon Neutral Days, and participation in a program called Bourse Carbone Scol'ÈRE). Two ASPnet schools, for instance, utilized climate change challenges. In Lion's Head, Ontario, as part of Bruce Peninsula District 
School's Simply Living Simply program, the entire K-12 school completed 10 monthly challenges focused on climate action (e.g., Go Local, Get Smart, and Get Moving). Each elementary class was responsible for a monthly climate change theme, wherein they developed three action-oriented challenges for the school and local community, which were communicated at monthly assemblies and on websites. Académie des Sacrés-Coeurs (in Saint-Bruno-de-Montarville, Quebec) was inspired by Bruce Peninsula District School to create 10 climate themed challenges that teachers could choose from to create projects. Similarly, Collège Regina Assumpta (in Montreal, Quebec) held a preCovid-19 Carbon Neutral Day after being inspired by the Carbon Neutral day held by Collège Sainte-Anne (in Lachine, Quebec), wherein the entire school community worked from home. Académie des Sacrés-Coeurs and École des Amis-du-Monde (in Côte Saint-Luc, Quebec) both participated in the Bourse Carbone Scol'ÈRE program, in which students first learn about reducing emissions, then teach others, including their families, about eco-friendly lifestyles. These examples illustrate the power of networking for climate action.

This key finding was incorporated into a subsequent CCE primer SEPN created in response to a partnership with a local school division, Saskatoon Public Schools, which was instigated by student action related to the Global Climate Strikes. Collaboration between Saskatoon Public Schools and SEPN resulted in a formal Memorandum of Understanding with activities including the formation of a cross-subject and cross-grades teacher network on environmental issues and climate change, professional development with school division leadership, and research collaboration. While this network is an example of local action that resulted in part from key findings from SEPN's evaluation, school divisions in other areas could facilitate the establishment of similar networks and professional development opportunities related to CCE.

Several networks exist that schools can join internationally (e.g., UNESCO ASPnet and the EcoSchools program) and within and across nations (e.g., SEEDS Green Schools in Canada, and the North American Association for Environmental Education). Such networks and associations often provide online platforms to share ideas, problems, and resources.

\subsection{Actions Occurred in Both Pilot and Non-Pilot Schools}

Related to the previous finding about the power of networks, major differences between pilot and non-pilot ASPnet schools were not identified. There are several potential explanations for this finding. First, it is likely that the non-pilot schools that chose to respond to the survey were already engaged in climate action projects (17 out of 77 non-pilot schools responded to the survey). Additionally, both pilot and non-pilot ASPnet schools were already well positioned 
to offer transformative education prior to the Getting Climate-Ready project. A previous study on ASPnet schools in Alberta and Manitoba revealed that

ASPnet schools are unique in their willingness to cross the traditional boundaries between school and community, curriculum and subject area, age and grade, ability and disability, local focus and global concern. Such a willingness to move beyond accepted thinking gives ASPnet schools the potential to transform students into actively engaged citizens. (Shultz et al., 20o9, p. 2)

All schools joining the ASPnet network also make a commitment to support UNESCO's ideals through four pillars of learning, which align with the Delors Report (Delors et al., 1996) as well as four themes of study that span these pillars (UNESCO \& CCUNESCO, n.d.; see Table 3.1).

TABLE 3.1 The four pillars of learning from the Delors Report (1996) and the four themes of study for UNESCO ASPnet schools

Pillars of learning

Learning to live together

Learning to be

Learning to do

Learning to know
Themes of study

Intercultural Learning

Global Citizenship Education (GCED)

Education for Sustainable Development (ESD)

UNESCO and UN Priorities

That the pillars of learning and themes of study were pre-established likely eased implementation of the Getting Climate-Ready project (for pilot schools) and aligned with practices already occurring (especially in non-pilot schools). The pillars of learning align with the elements of "good" CCE mentioned above (namely, cognitive with "learning to know", socio-emotional with "learning to be", behavioral with "learning to do", and justice-oriented with "learning to live together"), which likely further aided implementation. Prior work at the pilot and non-pilot schools in relation to the pillars of learning and themes of study likely meant that many schools were already undertaking climate action projects before the Getting Climate-Ready project commenced.

\subsection{Integrated Climate Action within and across Domains}

An important element of a whole institution approach is incorporating climate action within and across as many domains of institutional activity as possible. 
The more domains included, the stronger and more established the culture of sustainability at the school (UNESCO, 2016). Across pilot and non-pilot ASPnet schools, almost all the climate actions identified were integrated into more than one domain. At École Francophone d'Airdrie in Airdrie, Alberta, for example, a three-year school plan (domain: school governance) led to the creation of a mini-UNESCO conference, at which students learn from each other and the community about an annual theme (domains: teaching and learning; community partnerships). The theme in 2018 was climate change. Bairdmore School, in Winnipeg, Manitoba, has established a funding partnership with the school's advisory council to apply for grants (domains: school governance; community partnerships) to support an outdoor classroom, which encourages outdoor play and sustainable actions, such as growing vegetables and plants (domains: teaching and learning; facilities and operations).

Of the four whole institution areas, schools are typically focused on teaching and learning as their core mandate. Within this area, the emphasis is on incorporating CCE into all subjects in line with curricular outcomes (UNESCO, 2016). Several ASPnet schools were taking up the challenge to include CCE across all subjects, a practice that not only strengthens the culture of climate action at the school but also encourages students to understand climate change from a variety of perspectives. In Edmonton, Alberta, Queen Elizabeth High School incorporates ESD and climate action across all subjects and classes. CCE is also integrated across subjects at Bruce Peninsula District School in Ontario (see Figure 3.4).

\begin{tabular}{|l|l|}
\hline Subject & Activities \\
\hline The Arts & Art installations, Protest art, Posters, Energy plays \\
\hline English & Speeches, Monthly assembly presentations, Reflections \\
\hline Agriculture & School garden, Orchard, Indigenous tree planting \\
\hline Biology & Biological adaptation related to climate change \\
\hline Citizenship & Shoreline and roadside cleanup, Tree planting volunteers \\
\hline Geography & Carbon footprint around the world \\
\hline Health & Outdoor classrooms, Forest walks \\
\hline History & History of resource extraction to present day extraction \\
\hline Science & Inquiry based climate change projects \\
\hline Math & Climate change math-related problems \\
\hline Vocation & Tech class create raised beds for school garden \\
\hline
\end{tabular}

FIGURE 3.4 Sample of cross-curricular inclusion of climate change topics at Bruce Peninsula District School (from Bruce Peninsula District School, 2020)

While climate actions were incorporated across multiple domains within the ASPnet schools, many were oriented toward facilities and operations. This approach often relies on individuals' changing their own behaviors (for 
example, turning off lights). In the future, students could utilize critical thinking skills to determine the source of problems contributing to climate change. Schools could also adopt a climate action approach aimed at broader systemic social structures that support climate inaction. For example, students could engage with representatives in municipal, provincial, and federal government to advocate for broader governmental and policy change.

\subsection{Diverse Actors Engaged in Climate Action}

A whole institution approach was supported by interpersonal relationships led by diverse members of the school community, such as students of all ages, teachers, and members of the administrations. For example, at Collège Durocher Saint-Lambert in Saint-Lambert, Quebec, students research environmental topics and then visit other classes to educate students and teachers. Students at several schools also lead recycling programs (for example, École Beausejour in Plamondon, Alberta, and Hafford Central School in Hafford, Saskatchewan). At École La Source in Cornwallis, Manitoba, a school garden is cared for by teachers and students in collaboration with a community partner. A sustainable development policy established by school management at Collège Sainte-Anne led to their Carbon Neutral Day, which was held twice a year for three years. Engaging the entire school community develops a sense of agency and makes an integrated, whole institution approach possible.

While the ASPnet schools engaged individuals with different roles in climate action, the inclusion of a focus on other forms of diversity and climate justice represents an area for future growth. This issue is especially relevant in the international and Canadian context of Black Lives Matter protests. Indeed, calls for increased racial justice are inextricably linked to calls for climate justice by Indigenous peoples and other people of color (Lakhani \& Watts, 202O; Mersha, 2017).

Diversifying the type of knowledge within CCE may also strengthen future climate action projects. Indigenous knowledge, for example, is deeply embedded in caring for the land for future generations and often includes crucial locally relevant mitigation and adaptation strategies (Hosen et al., 2020; Nalau et al., 2018). Meaningful engagement with Indigenous communities can also make CCE more relevant to students through local connections to place, which benefit everyone, not just Indigenous learners, and which can become a catalyst for action (Restoule \& Chaw-win-is, 2017).

\subsection{The Role of Ministries of Education}

While the above sections mostly focus on emerging themes and suggested school-level actions from SEPN's CCUNESCO ASPnet schools evaluation, this 
section applies a whole institution approach to provincial (or state) ministries and regional school divisions.

Ministries of education can particularly support whole institution climate action through curricular frameworks and other policy initiatives. Prior SEPN research suggests that each level of education policy is important in ensuring that sustainability policies and practices are strong at local levels (McKenzie \& Aikens, 2020). A recent census of sustainability-specific policies within Canadian ministries of education found that $54 \%$ of provinces and territories had such policies, usually in relation to curriculum (Beveridge et al., 2019). For example, in the province of Saskatchewan, sustainability was addressed at the policy level only in relation to curriculum, indicating an opportunity for broader inclusion (Beveridge et al., 2019). While all 13 Canadian provinces and territories mention education in their climate policies, only $46 \%$ of provinces specifically mention climate change in their education policies (Bieler et al., 2018). When climate change is included, it is often only in relation to reducing school greenhouse gas emissions, representing a missed opportunity to include other whole institution areas (Bieler et al., 2018). Ministries of education can also meaningfully engage with policy actors at school and division levels to ensure broad support for policies developed, and to encourage school division level and school level policy (Chopin et al., 2017).

Another way ministries of education can address climate change is to include it within subject and grade specific curricula. When climate change is only rarely included in the curriculum, the indirect message sent to students is that it does not matter (Lawrynuik, 2019). Within Canada, including climate change in curricula also aligns with other ministry commitments, such as a 2016 agreement by all ministers of education to integrate six global competencies into curricula, including one on global citizenship and sustainability (CMEC, 2018). By choosing to mandate CCE in curriculum, ministries of education join similar initiatives in other nations (e.g., Italy, New Zealand) and cities (e.g., Islamabad) (Graham-McLay, 2020; Jones, 2019; Tunio, 2019).

Ministries of education can also implement or support provincial eco-certification programs for schools (Strobbe et al., 2014). Environmental certification programs provide environmental, educational, and economic benefits to schools and divisions (see Figure 3.5) by promoting the value of environmental education (and increasingly CCE), supporting schools and divisions to make environmentally friendly decisions, and rewarding schools that meet benchmarks along the way (Freake, 2015; Goodchild et al., 2017; Strobbe et al., 2014). While eco-certification programs are created by a range of groups from provincial governments to non-profit organizations, research suggests that the largest and perhaps most successful eco-certification programs are supported by 


\begin{tabular}{|l|l|}
\hline Environmental & $\begin{array}{l}\text { - Community strengthening through joint initiatives such as vegetable gardens } \\
\text { or waste free lunch programs }\end{array}$ \\
& $\begin{array}{l}\text { - Enhanced biodiversity from green school grounds } \\
\text { - Increased school aesthetics } \\
\text { - Reduction of school's ecological footprint }\end{array}$ \\
\hline $\begin{array}{l}\text { Educational } \\
\text { Benefits }\end{array}$ & $\begin{array}{l}\text { - Healthier students - socially, mentally, and behaviorally } \\
\text { - Increase in student and teacher awareness of environmental issues and } \\
\text { stewardship } \\
\text { - Richer curriculum } \\
\text { - Process of certification can lead to a new, collaborative vision for the school } \\
\text { - Professional development and leadership opportunities for students and } \\
\text { teachers }\end{array}$ \\
\hline $\begin{array}{l}\text { Economic } \\
\text { Benefits }\end{array}$ & $\begin{array}{l}\text { - Shole-school participation and community ownership } \\
\text { - Savings from reduced amount of waste due to recycling initiatives }\end{array}$ \\
\hline
\end{tabular}

FIGURE 3.5 Environmental, educational, and economic benefits of eco-certification in $\mathrm{K}-12$ schools (from Strobbe et al., 2014)

ministries of education (e.g., in Canada, British Columbia's Green Schools and Manitoba's EcoGlobe Program; Strobbe et al., 2014).

\subsection{The Role of School Divisions}

As mentioned above, each level of education policy is important in ensuring sustainability uptake at subsequent levels, which includes sustainability and climate change policy in school divisions (Bieler et al., 2018). SEPN's research found that $59 \%$ of Canadian regional school divisions have sustainability-specific policy of some type, usually focused on operations (Beveridge et al., 2019; see Figure 3.6). An opportunity exists for school divisions to add

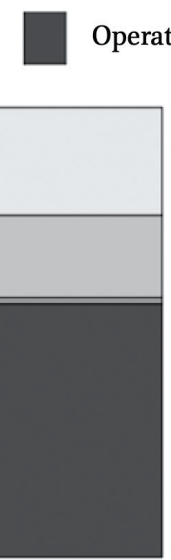

BC

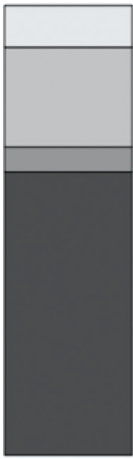

$\mathrm{AB}$
Outreach

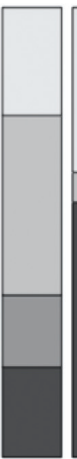

SK

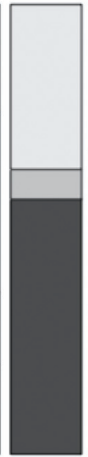

MB

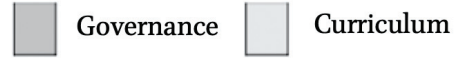

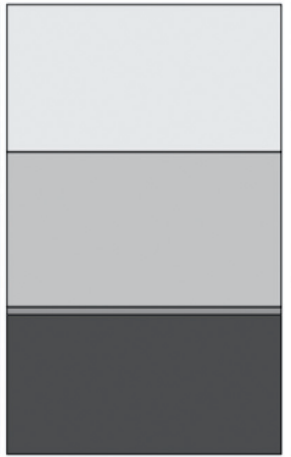

ON

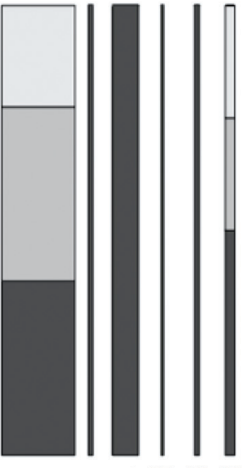

QC NB NS PE NL NT

Province/Territory

FIGURE 3.6 Whole institution areas covered by school division areas, by province (from Beveridge et al., 2019) 
climate-specific targets into these policy documents as well as to develop policies in areas beyond operations, such as curricular and pedagogical support, or community outreach.

School divisions have also responded to the climate crisis in other creative ways, including professional development for teachers and administrators, declaring climate emergencies, supporting climate strike participation, passing climate action resolutions, policies and plans, encouraging schools to include CCE at all grade levels, and developing monthly environmental challenges for staff and students (СВС, 2019a; Colorado Association of School Boards, 2019; Israelson, 2019; Rahim, 2019; Rainbow District School Board, 2019; Schools for Climate Action, n.d; CBC, 2019a; Toronto District School Board, 2010). Eco-certification program support is also growing in popularity among school divisions, with SEPN finding $43 \%$ of school divisions participating in this programming (McKenzie \& Aikens, 2020). Some suggestions for future and continued action are provided in Figure 3.7.

In Saskatchewan, Canada, Saskatoon Public Schools and Greater Saskatoon Catholic Schools are collaborating on the Student Action for a Sustainable Future program (Saskatchewan Environmental Society, 2019). The program is an inquiry and action project for Grade 5 to 8 classrooms. Each year 12 classes are chosen to participate in the program, which is coordinated by the City of Saskatoon. Co-partners also include the Saskatchewan Environmental Society, Saskatoon Light and Power, and the Sustainability Education Research Institute. Supported by these partners and with the goal of reducing greenhouse gas emissions in Saskatoon and around Saskatchewan, students develop action projects in the areas of waste, water, energy, food, biodiversity, and transportation (Saskatchewan Environmental Society, 2019).

School boards are responding to the climate crisis in unique ways across whole institution domains. Future actions could include expanding sustainability policies beyond an operations focus, as well as partnering more closely with students (e.g., inviting students to develop input concerning their municipality's emissions reduction plan and presenting their results to the city).

$\mathrm{K}-12$ education systems in Canada and elsewhere are taking significant steps to mitigate climate change. The many exciting climate action initiatives taking place provide an inspiring reminder of the power and promise of collective action in addressing climate change. While much more research is needed to determine what counts as "good" CCE, a whole institution approach is increasingly recommended to enable education systems to achieve collaborative 
What School Divisions Can Do Now in Each of the Four Whole Institution Areas

\begin{tabular}{|l|}
\multicolumn{1}{c|}{ GOVERNANCE } \\
- \\
Establish a sustainability portfolio and \\
hire sustainability staff \\
Establish an environmental committee to \\
support sustainable and climate friendly \\
initiatives \\
- Run an eco-certification program \\
through the division office and encourage \\
schools to participate \\
- Create a climate action plan with specific \\
measurable targets within all four whole \\
institution areas \\
- Create grants for eco-friendly projects to \\
incentivize schools \\
- Declare a climate emergency \\
Pass a climate resolution
\end{tabular}

COMMUNITY PARTNERSHIPS

- Partner with local organizations and/or provincial governments to install solar panels on school roofs and reduce carbon emissions

- Partner with the municipality or region to co-develop climate solutions

- Partner on CCE projects such as Student Action for a Sustainable Future

- Create a program connecting farmers to schools to discuss local effects of climate change

- Encourage schools to create gardens and share their crops with the school and local community

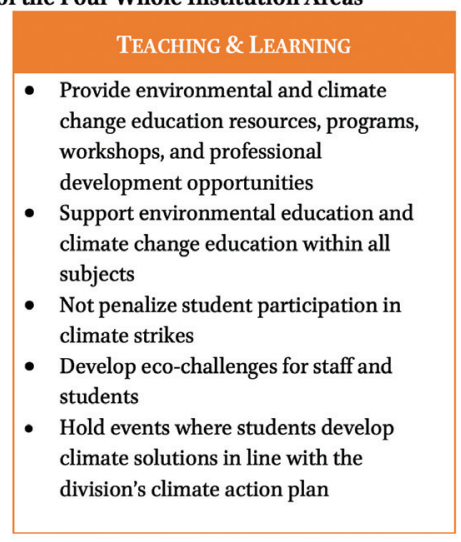

\section{FACILITIES \& OPERATIONS}

- Implement an anti-idling policy and use low emissions vehicles for school buses and division transportation

- Install solar panels on schools, water bottle fountains in all schools, low-flush toilets, and light timers

- Support schools to setup student led recycling and composting programs, and implement similar programs in division offices

- Issue carbon reduction challenges to encourage staff, students, and teachers to take eco-friendly transportation to school

- Develop policies supporting access to local food in school cafeterias

FIGURE 3.7 Actions school divisions can take within each of the whole institution domains (from Hargis \& McKenzie, 2020). (The literature that informed the creation of this figure: Beveridge et al., 2019; СBC, 2019b; Chopin et al., 2018; Colorado Association of School Boards, 2019; Greater Victoria School District, 2018; Hargis et al., 2018; Israelson, 2019; Pearson, 2014; Portland Public Schools, 2016; Rainbow District School Board, 2019; Saskatchewan Environmental Society, 2019; Schools for Climate Action, n.d.; СвС, 2019a; Thomson, 2016; Toronto School District Board, 2014)

action that moves away from individualistic climate change responses (Bieler et al., 2018; Henderson \& Tilbury, 2004; UNESCO, 2016).

The implementation of the UNEsco Getting Climate-Ready project within Canadian ASPnet schools resulted in examples of climate action in each of the whole institution areas. Recommendations for future and continued action in schools include: (1) establishing connections with local, national, or international networks and associations; (2) integrating climate action within and across domains; and (3) involving diverse peoples, knowledges, and perspectives in local action. 
Ministries of education can particularly support climate action through policies, curriculum frameworks, and subject-specific curricula (McKenzie \& Aikens, 2020). Many ministries are already responding to the climate crisis in unique ways. Specific recommendations for future action include: (1) expanding beyond curriculum in education policies; (2) incorporating climate change in educational policies, not just climate change policies; (3) including climate change in all subject curricula; and (4) supporting eco-certification programs.

Many school divisions are also incorporating climate action in each whole institution area. Recommendations for future action include: (1) expanding beyond an operations focus; (2) supporting eco-certification programs; and (3) partnering with other organizations and research institutes to deliver climate change related programming for students. Such partnerships with researchers, organizations, schools, and school divisions, can allow for unique opportunities for research to support climate action.

In the face of an enormous health crisis lies an immense opportunity to respond to UN Secretary-General António Guterres' call to "build back better" (Giannini, 2O2O; also see CCUNESCO \& UNESCO, 202O). As governments around the world restructure education systems to respond to Covid-19, we have "a once in a generation opportunity to improve education, alongside economies, to fight the climate crisis" (Giannini, 2020). Such a response should incorporate climate justice perspectives that challenge the intersecting inequities bolstered by capitalism (Godfrey \& Torres, 2016). As student and Canadian Indigenous water activist Autumn Peltier reminded us, "We can't eat money or drink oil" (СBC, 2019c). Climate change education provides an opportunity to engage students, teachers, and whole institutions in addressing climate change. We hope Canada, and others, take up the challenge to build back better in the years to come.

\section{Acknowledgment}

The authors would like to acknowledge SEPN Project Manager Nicola Chopin, whose efforts were crucial in co-designing and co-writing the CCUNEsco ASPnet evaluation and reports on which the text of this chapter is partially based.

\section{Note}

1 In some of SEPN's research a fifth domain of research is also included (see Beveridge et al., 2019). 


\section{References}

Amel, E., Manning, C., Scott, B., \& Koger, S. (2017). Beyond the roots of human inaction: Fostering collective effort toward ecosystem conservation. Science, 356, 275-279. https://doi.org/10.1126/science.aal1931

Beveridge, D., McKenzie, M., Aikens, K., \& Strobbe, K. (2019). A national census of sustainability in K-12 education policy: Implications for international monitoring, evaluation, and research. Canadian Journal of Educational Administration and Policy, 188, 36-52. https://journalhosting.ucalgary.ca/index.php/cjeap/article/view/42371

Bieler, A., Haluza-Delay, R., Dale, A., \& McKenzie, M. (2018). A national overview of climate change education policy: Policy coherence between subnational climate and education policies in Canada (K-12).Journal of Education for Sustainable Development, 11(2), 63-85. https://doi.org/10.1177/o973408218754625

Brownlee, M. T. J., Powell, R. B., \& Hallo, J. C. (2013). A review of the foundational processes that influence beliefs in climate change: Opportunities for environmental education research. Environmental Education Research, 19(1), 1-20. https://doi.org/ $10.1080 / 13504622.2012 .683389$

Bruce Peninsula District School. (2020). Teaching and learning. https://bpds.bwdsb.on.ca/

Callison, C. (2014). How climate change comes to matter: The communal life of facts. Duke University Press.

CBC [Canadian Broadcasting Corporation]. (2019a, September 18). Some Canadian schools, colleges move to accommodate climate strikes. $C B C$. https://www.cbc.ca/ news/canada/toronto/schools-climate-rally-1.5288179

CBC. (2019b, September 24). Vancouver School Board will allow students to skip class to attend global climate strikes. https://www.cbc.ca/news/canada/british-columbia/ vsb-climate-strike-vote-1.5294962

CBC. (2019c, September 28). Canadian Indigenous water activist Autumn Peltier addresses UN on clean water. $C B C$. https://www.cbc.ca/news/world/canadianindigenous-water-activist-autumn-peltier-addresses-un-on-clean-water-1.5301559

CCUNESCO [Canadian Commission for UNESCO] \& UNESCO. (2020, July 8). Investing in ecosystems: The cornerstone for sustainable renewal of the Canadian economy. https:/ipolitics.ca/2020/07/o8/investing-in-ecosystems-the-cornerstone-forsustainable-renewal-of-the-canadian-economy/

CCUNESCO [Canadian Commission for UNESCO]. (2020). Teachers' toolkit: UNESCO Schools Network in Canada. CCUNESCO.

Chopin, N. S., Hargis, K., \& McKenzie, M. (2018). Building climate-ready schools in Canada: Towards identifying good practices in climate change education. Sustainability and Education Policy Network, University of Saskatchewan. https://sepn.ca/ resources/report-building-climate-ready-schools-canada/ 
Chopin, N. S., McKenzie, M., Haluza-Delay, R., \& MacDonald, R. (2017). The influences on sustainability uptake in K-12 education policy development: A national survey of educators, administrators, and staff. Sustainability and Education Policy Network, University of Saskatchewan.

Clayton, S., Manning, C. M., Krygsman, K., \& Speiser, M. (2017). Mental health and our changing climate: Impacts, implications, and guidance. American Psychological Association \& ecoAmerica.

CMEC [Council of Ministers of Education Canada]. (2018). Global competencies. https://www.globalcompetencies.cmec.ca/global-competencies

Colorado Association of School Boards. (2019). 79th Annual Delegate Assembly. https://www.casb.org/assets/docs/Advocacy/2019\%2oResolution\%2oBooklet_ email\%2ocopy.pdf

Costello, A., Abbas, M., Allen, A., Ball, S., Bell, S., Bellamy, R., ... Patterson, C. (2009). Managing the health effects of climate change. Lancet, 373, 1693-1733. https://doi.org/10.1016/So14o-6736(o9)6o935-1

CRED [Center for Research on Environmental Decisions]. (2009). The psychology of climate change communication: A guide for scientists, journalists, educators, political aides, and the interested public. Columbia University. http://guide.cred.columbia.edu/ pdfs/CREDguide_full-res.pdf

Delors, J., Al Mufti, I., Amagi, I., Carneiro, R., Chung, F., Geremek, B., ... Zhou, N. (1996). Learning: The treasure within. UNESCO. https://unesdoc.unesco.org/ark:/48223/ pfoooo10959o?posInSet=12\&queryId=f9897ad1-e31b-4acf-a2d8-e64997ad28ab

Doherty, T. J., \& Clayton, S. (2011). The psychological impacts of global climate change. American Psychologist, 66(4), 265-276. https://doi.org/10.1037/aoo23141

Elks, S. (2019, September 19). Children suffering eco-anxiety over climate change, say psychologists. Reuters. https://www.reuters.com/article/us-britain-climatechildren/children-suffering-eco-anxiety-over-climate-change-say-psychologistsidUSKBN1W42CF

Freake, C. (2015). Have your say about climate change education. Green Schools Nova Scotia. https://www.greenschoolsns.ca/news/have-your-say-about-climate-changeeducation

Giannini, S. (2020, June 18). Build back better: Education must change after COVID-19 to meet the climate crisis. UNESCO. https://en.unesco.org/news/build-back-bettereducation-must-change-after-covid-19-meet-climate-crisis

Glikson, A. (2016). Cenozoic mean greenhouse gases and temperature changes with reference to the Anthropocene. Global Change Biology, 22(12), 3843-3858. https://doi.org/10.1111/gcb.13342

Godfrey, P. (2012). Introduction: Race, gender, \& class and climate change. Race, Gender and Class, 19(1-2), 3-11. https://www.jstor.org/stable/43496857

Godfrey, P., \& Torres, D. (Eds.). (2016). Systemic crises of global climate change: Intersections of race, class, and gender. Routledge. 
González-Gaudiano, E., \& Meira-Cartea, P. (2010). Climate change education and communication: A critical perspective on obstacles and resistances. In F. Kagawa \& D. Selby (Eds.), Education and climate change: Living and learning in interesting times (pp. 13-34). Routledge.

Goodchild, H., Padolsky, J., \& Cheng, T. (2017). Climate change learning \& action in Ontario's certified schools. EcoSchools Canada. https://www.ontarioecoschools.org/ wp-content/uploads/2018/o1/Climate-Change-Report-2017.pdf

Graham-McLay, C. (2020, January 13). New Zealand schools to teach students about climate crisis, activism and 'eco-anxiety'. The Guardian.

https://www.theguardian.com/world/2020/jan/13/new-zealand-schools-to-teachstudents-about-climate-crisis-activism-and-eco-anxiety

Greater Victoria School District. (2018, September 5). District installs new water fountains and bottle fillers in all schools. https://www.sd61.bc.ca/news-events/news/title/ district-installs-new-water-fountains-and-bottle-fillers-in-all-schools/

Hargis, K., Chopin, N. S., \& McKenzie, M. (2018). Ten Canadian schools'stories of climate action. Sustainability and Education Policy Network, University of Saskatchewan. https://sepn.ca/resources/report-ten-canadian-schools-stories-climate-action/

Hargis, K., \& McKenzie, M. (2020). Responding to climate change education: A primer for $K-12$ education. Sustainability and Education Policy Network, University of Saskatchewan.

Henderson, K., \& Tilbury, D. (2004). Whole-school approaches to sustainability: An international review of sustainable school programs. Macquarie University.

Hornsey, M. J., Harris, E. A., Bain, P. G., \& Fielding, K. S. (2016). Meta-analyses of the determinants and outcomes of belief in climate change. Nature: Climate Change, 6 , 622-626. https://doi.org/10.1038/nclimate2943

Hosen, N., Nakamura, H., \& Hamzah, A. (2020). Adaptation to climate change: Does traditional ecological hold the key? Sustainability, 12(2), 676. https://doi.org/10.339o/ su12020676

IPCC [Intergovernmental Panel on Climate Change]. (2018). Global warming of 1.5 C. https://www.ipcc.ch/sri5/

Israelson, D. (2019, October 15). Climate change compels schools to improve environmental literacy. Globe and Mail. https://www.theglobeandmail.com/featured-reports/article-climate-crisis-compels-schools-to-improve-environmental-literacy/

Jandu, N. (2020, May 13). Human activity is responsible for animal viruses crossing over and causing pandemics. Medical Express. https://medicalxpress.com/news/ 2020-O5-human-responsible-animal-viruses-pandemics.html

Johnson, D. (2007, April 16). Climate change scenarios scare, and motivate, kids. The Washington Post. http://www.washingtonpost.com/wp-dyn/content/article/2007/ 04/15/AR200704150 1164.html

Jones, G. (2019, November 5). Exclusive: Italy to make climate change study compulsory in schools. Reuters. https://www.reuters.com/article/us-climate-change-italy- 
exclusive/exclusive-italy-to-make-climate-change-study-compulsory-in-schoolsidUSKBN1XF1E1

Kahan, D. M., Peters, E., Wittlin, M., Slovic, P., Ouellette, L. L., Braman, D., \& Mandel, G. (2012). The polarizing impact of science literacy and numeracy on perceived climate change risks. Nature: Climate Change, 2, 732-735. https://doi.org/10.1038/ nclimate 1547

Kanbur, R. (2015). Education for climate justice: The many faces of climate justice: An essay series on the principles of climate justice. Mary Robinson Foundation, Trinity College. http://www.mrfcj.org/pdf/faces-of-climate-justice/Education-for-ClimateJustice.pdf

Lakhani, N., \& Watts, J. (2020, June 18). Environmental justice means racial justice, say activists. The Guardian. https://www.theguardian.com/environment/2020/jun/ 18/environmental-justice-means-racial-justice-say-activists?fbclid= IwAR2JpEFc2gSTfDnYUqPI_A55ootzzzDqt-1Rjx-QHEVYrlMPGXo_lRYEN1g

Lawrynuik, S. (2019, July 10). 'It's kind of frightening': Students worry climate change education lacking in Alberta classrooms. The Narwhal. https://thenarwhal.ca/itskind-of-frightening-students-worry-climate-change-education-lacking-in-albertaclassrooms/

Lee, T. M., Markowitz, E. M., Howe, P. D., Ko, C.-Y., \& Leiserowitz, A. A. (2015). Predictors of public climate change awareness and risk perception around the world. Nature: Climate Change, 5, 1014-1020. https://doi.org/10.1038/nclimate2728

Li, C. J., \& Monroe, M. C. (2017). Exploring the essential psychological factors in fostering hope concerning climate change. Environmental Education Research, 5, 1-19. https://doi.org/10.1080/13504622.2017.1367916

McKenzie, M., \& Aikens, K. (2020). Global education policy mobilities and subnational policy practice. Globalisation, Societies and Education. https://doi.org/10.108o/ 14767724.2020.1821612

Mersha, S. (2017). Black lives and climate justice: Courage and power in defending communities and Mother Earth. Third World Quarterly, 39(7), 1421-1434. https://doi.org/10.1080/01436597.2017.1368385

Monroe, M. C., Plate, R. R., Oxarart, A., Bowers, A., \& Chaves, W. A. (2017). Identifying effective climate change education strategies: A systematic review of the research. Environmental Education Research, 1-22. https://doi.org/10.1080/ 13504622.2017.1360842

Morens, D. M., \& Fauci, A. S. (2020). Emerging pandemic diseases: How we got to Covid-19. Cell, 182, 1077-1092. https://doi.org/10.1016/j.cell.2O20.08.o21

Nalau, J., Becken, S., Schliephack, J., Parsons, M., Brown, C., \& Mackey, B. (2018). The role of Indigenous and traditional knowledge in ecosystem-based adaptation: A review of the literature and case studies from the Pacific Islands. Weather, Climate, and Society, 10(4), 851-865. https://doi.org/10.1175/WCAS-D-18-0o32.1 
Norgaard, K. M. (2011). Living in denial: Climate change, emotions, and everyday life. MIT Press.

Ojala, M. (2017). Hope and anticipation in education for a sustainable future. Futures, 94, 76-84. https://doi.org/10.1016/j.futures.2016.10.004

Orr, D. W. (2011). Hope is an imperative: The essential David Orr. Island Press.

Pearson, W. (2014, September 6). Seine River School talks anti-idling.

http://climatechangeconnection.org/fresh_stories/seine-river-school-divisiontalks-anti-idling/

Plutzer, E., McCaffrey, M., Hannah, A. L., Rosenau, J., Berbeco, M., \& Reid, A. H. (2016). Climate confusion among US teachers: Teacher's knowledge and values can hinder climate education. Science, 351(6274), 664-665. https://doi.org/10.1126/ science.aab39o7

Portland Public Schools. (2016). Resolution no. 5272: Resolution to develop an implementation plan for climate literacy. https://www.pps.net/cms/lib8/ORo19

Rahim, Z. (2019, September 27). Greta Thunberg leads climate march in Montreal: 'We've become too loud for people to handle'. Independent.

https://www.independent.co.uk/environment/greta-thunberg-climate-marchmontreal-canada-justin-trudeau-a9123991.html

Rainbow District School Board. (2019). Rainbow Board declares climate change emergency and commits to further action. https://www.rainbowschools.ca/news/rainbowboard-declares-climate-change-emergency-and-commits-to-further-action/ ?sfns $=$ mo

Randall, R. (2009). Loss and climate change: The cost of parallel narratives. Ecopsychology, 1(3), 118-129. https://doi.org/10.1089/eco.2009.0034

Restoule, J.-P., \& Chaw-min-is. (2017). Old ways are the new way forward: How Indigenous pedagogy can benefit everyone. Canadian Commission for UNESCO's IdeaLab. https://en.ccunesco.ca/-/media/Files/Unesco/OurThemes/EncouragingInnovation/ 20171026_Old-ways-are-the-new-way-forward_How-Indigenous-pedagogy-canbenefit-everyone_FINAL.pdf

Rowling, M. (2019, September 24). UN climate summit exposes struggle to ditch fossilfuel 'status quo'. Reuters. https://www.reuters.com/article/us-climate-changesummit-policy/u-n-climate-summit-exposes-struggle-to-ditch-fossil-fuel-statusquo-idUSKBNiW924R

Saskatchewan Environmental Society. (2019). Student action for a sustainable future. http://environmentalsociety.ca/programs/k-12-school-programs/sasf/

Schools for Climate Action. (n.d.). School boards. https://schoolsforclimateaction.weebly.com/

SDSN [Sustainable Development Solutions Network]. (2015). Indicators and a monitoring framework for the Sustainable Development Goals: Launching a data revolution for the SDGs. https://ec.europa.eu/knowledge4policy/publication/indicatorsmonitoring-framework-sustainable-development-goals-launching-datarevolution_en 
Shultz, L., \& Guimares-Iosif, R. (2012). Citizenship education and the promise of democracy: A study of UNESCO associated schools in Brazil and Canada. Education, Citizenship \& Social Justice, 7(3), 241-254. https://doi.org/10.1177/1746197912448712

Shultz, L., Guimaraes-Iosif, R., Chana, T., \& Medland, J. (2009). The impact of becoming a UNESCO ASPnet school in Alberta and Manitoba, Canada. Alberta Teachers' Association.

Stevenson, K., \& Peterson, N. (2016). Motivating action through fostering climate change hope and concern and avoiding despair among adolescents. Sustainability, 8(1), 6. https://doi.org/10.339o/su80100o6

Strobbe, K., Young, A., McKenzie, M., \& Beveridge, R. M. (2014). K-12 environmental certification programs: Building greener schools and environmental citizens. Sustainability and Education Policy Network, University of Saskatchewan.

Thomson, S. (2016, October 26). Alberta government will fund solar panels for new school projects. Edmonton Journal. https://edmontonjournal.com/news/localnews/alberta-government-will-fund-solar-panels-for-new-school-projects

Threadgold, S. (2012). 'I reckon my life will be easy, but my kids will be buggered': Ambivalence in young people's positive perceptions of individual futures and their visions of environmental collapse. Journal of Youth Studies, $15,17-32$. https://doi.org/ $10.1080 / 13676261.2011 .61849$ o

Toronto District School Board. (2010). Go green: Climate change action plan. http://ppf.tdsb.on.ca/uploads/files/live/92/1756.pdf

Tuck, E., \& McKenzie, M. (2015). Place in research: Theory, methodology, and methods. Routledge.

Tunio, H. (2019, November 14). Schools across Islamabad to teach climate change. The Express Tribune. https://tribune.com.pk/story/2099275/1-schools-across-islamabadteach-climate-change/?fbclid=IwAR${ }_{3} \mathrm{Kgh}_{3} \mathrm{KZQrV}_{-}$ iYjqHAKQPbJqlySP4P9PLZoh5qAVq4WudbbIZbB3sss4aY

UNESCO. (2010). The UNESCO climate change initiative: Climate change education for sustainable development. https://unesdoc.unesco.org/ark:/48223/pfoooo190101

UNESCO. (2015). Global citizenship education: Topics and learning objectives. Paris. https://unesdoc.unesco.org/ark:/48223/pfoooo232993

UNESCO. (2016). Getting climate-ready: A guide for schools on climate action. Paris. https://unesdoc.unesco.org/ark:/48223/pfoooo246740

UNESCO. (2018). UNESCO Associated Schools Network: Guide for national coordinators. https://unesdoc.unesco.org/ark:/48223/pfoooo261994

UNESCO. (2019a). Country progress on climate change education, training, and public awareness: An analysis of country submissions under the United Nations Framework Convention on climate change. https://unesdoc.unesco.org/ark:/48223/ pfoooo372164?posInSet=1\&queryId=6o6ce829-24c1-4b4f-99fc-743fo 4 b68710 
UNESCO. (2019b). Educational content up close: Examining the learning dimensions of education for sustainable development and global citizenship education. https://unesdoc.unesco.org/ark:/48223/pfoooo372327?posInSet=1\&queryId= 52ab3d5c-5ed9-468b-be8c-ffae75o221f6

UNESCO. (2020). Policy dialogue 4: Education for sustainable development and climate change. http://www.unesco.org/education/tlsf/mods/theme_c/img/ unescopolicydialogue.pdf

UNESCO \& Canadian Commission for UNESCO. (n.d.). UNESCO Associated Schools Network: Guide for school membership in Canada.

UNESCO \& UNFCCC. [United Nations Framework Convention on Climate Change]. (2016). Action for climate empowerment: Guidelines for accelerating solutions through education, training and public awareness.

UNFCCC. (1992). United Nations Framework Convention on Climate Change. United Nations. https://unfccc.int/resource/docs/convkp/conveng.pdf

UNFCCC. (2015). Adoption of the Paris Agreement. 21st Conference of the Parties.

United Nations. (2019). Climate justice. https://www.un.org/sustainabledevelopment/ blog/2019/05/climate-justice/

Watts, N., Amann, M., Ayeb-Karlsson, S., Belesova, K., Bouley, T., Boykoff, M., ... A. (2018). The Lancet countdown on health and climate change: From 25 years of inaction to a global transformation for public health. Lancet, 391(10120), 581-630. https://doi.org/10.1016/So140-6736(17)32464-9

Wibeck, V. (2014). Enhancing learning, communication and public engagement about climate change: Some lessons from recent literature. Environmental Education Research, 20(3), 387-411. https://doi.org/10.1080/13504622.2013.812720

WHO [World Health Organization]. (n.d.). Climate change and human health - Risks and responses: Summary. https://www.who.int/globalchange/summary/en/ index $5 . \mathrm{html}$

WHO. (2020). WHO Coronavirus disease (COVID-19) dashboard. https://covidig.who.int/

Wynes, S., \& Nicholas, K. A. (2019). Climate science curricula in Canadian secondary schools focus on human warming, not scientific consensus, impacts or solutions. PLoS ONE, 14(7), eo218305. https://doi.org/10.1371/journal.pone.0218305 